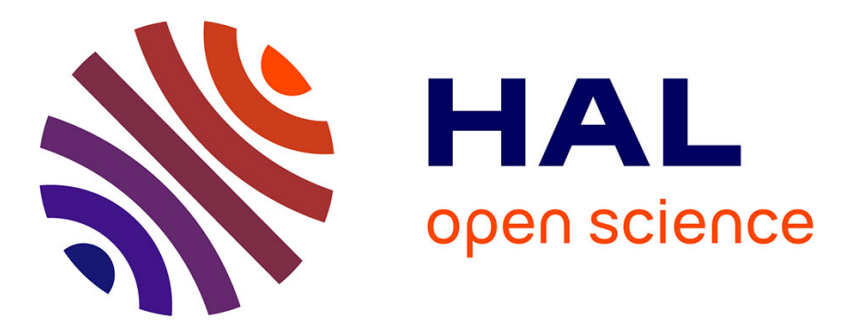

\title{
Evidence for mast cell, leukotriene and nitric oxide involvement in the regulation of the adrenoceptor number of inflamed small intestine in guinea pigs
}

\author{
J.P. Martinolle, Rafael Garcia Villar, Lionel Bueno
}

\section{To cite this version:}

J.P. Martinolle, Rafael Garcia Villar, Lionel Bueno. Evidence for mast cell, leukotriene and nitric oxide involvement in the regulation of the adrenoceptor number of inflamed small intestine in guinea pigs. Journal of Neurogastroenterology and Motility, 1995, 7, pp.187-195. hal-02706718

\section{HAL Id: hal-02706718 \\ https://hal.inrae.fr/hal-02706718}

Submitted on 1 Jun 2020

HAL is a multi-disciplinary open access archive for the deposit and dissemination of scientific research documents, whether they are published or not. The documents may come from teaching and research institutions in France or abroad, or from public or private research centers.
L'archive ouverte pluridisciplinaire HAL, est destinée au dépôt et à la diffusion de documents scientifiques de niveau recherche, publiés ou non, émanant des établissements d'enseignement et de recherche français ou étrangers, des laboratoires publics ou privés.

\section{다(1)(2)}

Distributed under a Creative Commons Attribution - ShareAlikel 4.0 International 


\title{
Evidence for mast cell, leukotriene and nitric oxide involvement in the regulation of the adrenoceptor number of inflamed small intestine in guinea pigs
}

\author{
J.-P. MARTINOLLE, R. GARCIA-VILLAR, J. MORE \& L. BUENO
}

INRA, Department of Pharmacology \& Toxicology, F-31931 Toulouse, France

\begin{abstract}
Changes in the populations of neurotransmitter receptors involved in the control of intestinal smooth muscle function have been associated with the altered motility of the inflamed gut. Thus, trinitrobenzenesulphonic acid (TNBS)-induced gut inflammation is accompanied by an increase in $\alpha$ - and a decrease in $\beta$ adrenoceptor numbers in guinea pig small intestine. In the present study, we investigated the effects of antiinflammatory compounds (cyclooxygenase inhibitor indomethacin, lipooxygenase inhibitor MK-886, nitric oxide synthase inhibitor $N^{G}$-nitro-L-arginine methylester ( $\mathrm{L}-N A M E$ ), mast cell stabilizer doxantrazole) on TNBS-induced adrenoceptor changes. Smooth muscle adrenoceptor populations, labelled by subtype-specific radioligands 6 days after TNBS, were significantly different from those of sham-treated controls: $\alpha 1$ - and a2-adrenoceptor numbers increased by more than $50 \%$, while $\beta$-adrenoceptor numbers decreased by more than $50 \%$. These changes, associated with severe inflammation as assessed histologically and by myeloperoxidase assay, were prevented by doxantrazole or L$N A M E$, and only partly by $M K-886$. In contrast, indomethacin did not prevent these changes. It appeats then that: (a) mast cell mediators, nitric oxide and leukotrienes are likely to contribute to TNBS-induced changes in adrenoceptor populations in the guinea pig inflamed intestine; (b) there is no evidence for prostanoid involvement in this process. It was suggested that changes in smooth muscle adrenoceptor populations may be an important mechanism by which gut inflammation alters intestinal motility.
\end{abstract}

Address for correspondence

Dr Rafael Garcia-Villar, INRA, Department of Pharmacology \& Toxicology, 180 chemin de Tournefeuille, BP.3, 31931 Toulouse, France

Received: 19 December 1994

Accepted for publication: 12 April 1995
Keywords adrenoceptor, inflammation, intestinal motility, leukotriene; mast cell, nitric oxide.

\section{INTRODUCTION}

Intestinal inflammation is associated with altered intestinal motility both in the human ${ }^{1}$ and animal species. ${ }^{2}$ The mechanisms underlying these motility disturbances are poorly understood, but may follow alterations in intestinal smooth muscle receptors and/or innervation. Indeed, marked suppression of the norepinephrine release from the myenteric plexus has been described in the inflamed intestine of rats infected by Trichinella spiralis. ${ }^{3}$ We have previously reported changes in the concentrations of smooth muscle adrenoceptors in trinitrobenzenesulphonic (TNBS) acidinflamed small intestine in guinea pigs. ${ }^{4}$ Nevertheless, the mechanisms underlying these changes in smooth muscle adrenoceptor number are not precisely known.

Infiltration of intestinal tissues by lymphocytes, eosinophils and neutrophils, ${ }^{5,6}$ as well as increased mast cell counts, ${ }^{7,8}$ are observed during gut inflammation. Moreover, prostaglandins (PGs) and leukotrienes (LTs), the concentrations of which are increased during inflammation, are probably involved in the course of intestinal inflammatory conditions. ${ }^{9,10}$ Nitric oxide (NO) is also strongly involved in intestinal inflammation, as evidenced by an enhanced release of NO in response to gut injury and the improvement of the inflammatory condition by treatment with NO synthase inhibitors. ${ }^{11,12}$

Pharmacological tools with putative antiinflammatory potential may prove useful in determining possible mechanisms: mast cell degranulation can be prevented by the mast cell stabilizer doxantrazole, ${ }^{13}$ NO generation can be blocked using the NO synthase inhibitor $\mathrm{N}^{\mathrm{G}}$-nitro-L-arginine methylester (L-NAME), ${ }^{12}$ leukotrienes by the lipooxygenase inhibitor MK- $886^{14}$ 
and prostanoids by the prostaglandin synthase inhibitor indomethacin. ${ }^{15}$ With this specific aim, we performed $\left[{ }^{3} \mathrm{H}\right]$ prazosin, $\left[{ }^{3} \mathrm{H}\right] \mathrm{rau}$ wolscine and $\left[{ }^{3} \mathrm{H}\right]$ dihydroalprenolol (DHA) binding in order to label $\alpha 1-, \alpha 2-$ and $\beta$ adrenoceptors, respectively, in smooth muscle membranes from both 'sham-treated' and 'TNBS-treated' animals, which received these different pharmacological treatments. In parallel, the activity of the enzyme myeloperoxidase (MPO) was assessed and histological studies were performed in order to evaluate neutrophil activation and intestinal tissue damage associated with TNBS experimental inflammation.

\section{METHODS}

\section{Animal preparation and experimental inflammatión}

The study was conducted in ten groups of six male guinea pigs (Interfauna, Loches, France) weighing 300$350 \mathrm{~g}$. After a $24-\mathrm{h}$ fast, the animals were submitted to abdominal laparotomy under aseptic conditions and deep anaesthesia (acepromazine, $2 \mathrm{mg} \mathrm{kg}^{-1}$; ketaminc $80 \mathrm{mg} \mathrm{kg}^{-1}$; intraperitoneally, i.p.). Animals received intrajejunally at day 0 either $0.3 \mathrm{ml} 0.9 \% \mathrm{NaCl}$ (five 'sham-treated' groups'), or $0.3 \mathrm{ml}$ of a mixture of TNBS (80 mg kg-1) in $50 \%$ ethanol solution (five 'TNBStreated' groups). (Throughout the present paper 'TNBS' will stand for 'TNBS in 50\% ethanol solution' which, both together, constitute the actual inflammatory compound.)

\section{Animal treatments}

In addition to the intrajejunal instillation of saline at day 0 , animals of the so-called 'sham-treated' groups were given twice a day during 7 days (i.e. from day -1 to day 5 ) the following treatments. 'Control group': saline alone $(0.3 \mathrm{ml} \mathrm{NaCl} 0.9 \%$, i.p); 'DOX group': the mast cell stabilizer doxantrazole $\left(5 \mathrm{mg} \mathrm{kg}^{-1}\right.$, i.p. $)$ in $0.3 \mathrm{ml}$ saline, ${ }^{13}$ 'MK group': the lipooxygenase inhibitor MK886 (5 $\mathrm{mg} \mathrm{kg}^{-1}$, orally) in $0.3 \mathrm{ml}$ saline, ${ }^{14}$ 'NAME group': the NO synthase inhibitor L-NAME $\left(10 \mathrm{mg} \mathrm{kg}^{-1}, \mathrm{i}\right.$.p. $)$ in $0.3 \mathrm{ml}$ saline, ${ }^{12}$ 'INDO group': the cyclooxygenase inhibitor indomethacin ( $\left.1 \mathrm{mg} \mathrm{kg}^{-1}, \mathrm{i} . \mathrm{m}.\right)$ in $0.3 \mathrm{ml} 5 \%$ sodium bicarbonate solution. ${ }^{15}$

Similarly, in addition to the intrajejunal instillation of $0.3 \mathrm{ml}$ TNBS solution at day 0 , animals of the so-called 'TNBS-treated' groups were given twice a day during 7 days (i.e. from day -1 to day 5) treatments similar to those described above, to constitute the following experimental groups: 'TNBS', 'TNBS-DOX', 'TNBSINDO', 'TNBS-MK and 'TNBS-NAME', respectively.
Animals were killed 6 days after intrajejunal injection of saline or TNBS. Before being killed by exanguination animals were anaesthetized with urethane $(100 \mathrm{mg}$ $\mathrm{kg}^{-1}$, i.p.). The small intestine was rapidly collected and thoroughly rinsed in ice-cooled physiological saline solution. All procedures were approved by the local INRA Animal Care and Use Committee.

\section{Histology}

For each animal, five pieces of ileum (about $0.5 \mathrm{~cm}$ each) were randomly collected for histological studies from 20 to $10 \mathrm{~cm}$ oral to the ileo-cecal junction, and rapidly immersed in $10 \%$ buffered formalin for $24 \mathrm{~h}$ in an attempt to evaluate the extent of inflammatory damages as well as the effects of the various treatments described above. After dehydration through graded strengths of ethanol, intestinal samples were cleared in xylene and imbedded in Histomed ${ }^{\circledR}$ standard (Labo Moderne, Paris, France). Transverse sections were cut at a thickness of 5 $\mu \mathrm{m}$, deparaffinized in xylene and rehydrated through an ethanol series. Thereafter, slides were routinely stained with haemalum and eosine.

\section{Myeloperoxidase activity assay}

The activity of intestinal myeloperoxidase (MPO), a specific enzyme marker of polymorphonuclear neutrophil primary granules, was measured in samples prepared from full thickness ileal wall fractions according to the method of Bradley et al ${ }^{16}$ with slight modifications. A small piece of ileum (about $0.5 \mathrm{~cm}$ ) was suspended in hexadecyl trimethylammonium bromide buffer (HTAB $0.5 \%$ in $50 \mathrm{~mm}$ phosphate buffer, $\mathrm{pH} 6.0$ ), a detergent that releases MPO from the primary granules. Intestinal tissues were minced with scissors, homogenized using a Polytron ( $20 \mathrm{sec}$, at maximal setting) and then filtered through two layers of surgical gauze. The remaining filtrate was sonicated on ice $(10 \mathrm{sec})$ and centrifuged at $40000 \times \mathrm{g}$ for $15 \mathrm{~min}$ at $4^{\circ} \mathrm{C}$. The pellet was discarded and the supernatant was assayed spectrophotometrically for MPO activity: $0.1 \mathrm{ml}$ of supernatant was combined with $2.9 \mathrm{ml}$ of $50 \mathrm{~mm}$ phosphate buffer (pH 6.0), containing $0.167 \mathrm{mg} \mathrm{ml}^{-1} \mathrm{O}$-dianisidine hydrochloride and $0.0005 \%$ hydrogen peroxide. The kinetics of changes in absorbance at $460 \mathrm{nM}$ were measured with an Uvikon 860 spectrophotometer (Kontron Instruments, St Quentin-en-Yvelines, France). The protein concentration was determined by the method of Lowry (Bio-Rad Detergent Compatible Protein Assay, Bio-Rad, Ivry, France) and MPO activity expressed as IU $\mathrm{mg}^{-1}$ of protein. One IU of MPO activity was defined as that 
degrading $1 \mathrm{~nm}$ of peroxide per minute at $25^{\circ} \mathrm{C}$. The assay sensitivity was $0.1 \mathrm{IU} \mathrm{ml} \mathrm{m}^{-1}$ and the mean intraassay coefficient of variation was $4 \%$.

\section{Membrane preparation}

A portion of about $50 \mathrm{~cm}$ of jejuno-ileum ending at 10 cm oral to the ileo-cecal junction was excised, cut open lengthwise and rinsed with ice-cooled physiological saline. The mucosa was removed under a stereomicroscope, so that only smooth muscle layers with the inherent enteric nerves remained. The tissue was minced with scissors, crushed in an electric mill, and homogenized with a Polytron (three bursts of $10 \mathrm{sec}$ at maximal setting, interspersed with 20 -sec cooling intervals) in 10 volumes of ice-cold physiological buffer solution ( $\mathrm{pH} 7.4)$ consisting of $(\mathrm{mM}): \mathrm{KCl}, 4.6 ; \mathrm{MgSO}_{4}$, 1.16; $\mathrm{CaCl}_{2}, 2.5 ; \mathrm{NaH}_{2} \mathrm{PO}_{4}, 1.16 ; \mathrm{NaCl}, 115.5$; $\mathrm{NaHCO}_{3}, 21.9$ and glucose, 11.1. The homogenate was centrifuged twice at $1000 \times g$ for $10 \mathrm{~min}$ at $4^{\circ} \mathrm{C}$, with intermediate rinsing and resuspension in ice cold buffer using a glass/glass Potter (Braun, Melsungen, Germany). The supernatants were again centrifuged twice at 10000 $\times g$ for $10 \mathrm{~min}$ at $4^{\circ} \mathrm{C}$; the pellets were discarded while the resulting supernatants were centrifuged at 100000 $\times g$ for 30 min at $4^{\circ} \mathrm{C}$. The final supernatant was discarded and the pelleted membranes were weighted and resuspended in a buffer volume adequate to get a final protein concentration of $1-3 \mathrm{mg} \mathrm{ml}^{-1}$ (Bio-Rad Protein Assay, Bio-Rad, Ivry, France). This subcellular fraction, contained mainly myocyte (i.e. postjunctional) plasma membranes but also, some innermost components of myenteric innervation (i.e. prejunctional synaptosomes). ${ }^{17-19}$

\section{Binding assay}

Adrenoceptor subtypes were characterized by binding of tritiated radioligands, $\left[{ }^{3} \mathrm{H}\right]$ prazosin, $\left[{ }^{3} \mathrm{H}\right]$ rauwolscine and $\left[{ }^{3} \mathrm{H}\right] \mathrm{DHA}$ labelling $\alpha 1-, \alpha 2$ - and $\beta$-adrenoceptors, respectively. Binding conditions for the three radioligands (i.e. buffers, time and temperature of incubation) were previously described. ${ }^{4}$ Buffers $(\mathrm{pH} 7.4)$ were: 50 $\mathrm{mM}$ TRIS-HCl, $10 \mathrm{mM} \mathrm{MgCl}_{2}$ for $\left[{ }^{3} \mathrm{H}\right.$ |prazosin and $\left[{ }^{3} \mathrm{H}\right] \mathrm{DHA}$ binding, and $20 \mathrm{mM}$ MOPS-Na, $0.5 \mathrm{mM} \mathrm{MgCl}_{2}$ for $\left[{ }^{3} \mathrm{H}\right]$ rauwolscine binding. Incubations were performed in duplicate for $30 \mathrm{~min}$ at $30^{\circ} \mathrm{C}$. The total volume of the reaction mixture was $400 \mu \mathrm{l}$ and contained $85-120$ $\mu \mathrm{g}$ of membrane protein. For $\alpha 1$-adrenoceptor saturation studies, 0.0125-2 nM $\left[{ }^{3} \mathrm{H}\right]$ prazosin were added; nonspecific binding was measured in the presence of $20 \mu \mathrm{M}$ of unlabelled prazosin. For $\alpha 2$-adrenoceptor saturation studies, $0.25-15 \mathrm{nM}\left[{ }^{3} \mathrm{H}\right]$ rauwolscine were added; non- specific binding was measured in the presence of $20 \mu \mathrm{M}$ of unlabelled yohimbine. For $\beta$-adrenoceptor saturation studies, $0.25-15 \mathrm{nM}\left[{ }^{3} \mathrm{H}\right] \mathrm{DHA}$ were added and nonspecific binding was measured in the presence of $20 \mu \mathrm{M}$ alprenolol. Incubation was stopped by adding $4 \mathrm{ml}$ icecold incubation buffer to the tubes. Bound radioactivity was separated by filtration through Whatman $\mathrm{GF} / \mathrm{C}$ glass-fibre filters, presoaked in buffer containing $0.3 \%$ polyethylenimine (used to reduce the amount of radioactivity unspecifically adsorbed to the filter). Filters were washed twice with $10 \mathrm{ml}$ ice-cold buffer, dried under vacuum, and placed into $4 \mathrm{ml}$ scintillation solution (Pico-fluor, Packard, Rungis, France). Radioactivity was measured with a liquid scintillation counter (Betamatic V, Kontron Instruments, St Quentin-en-Yvelines, Francel with an efficiency of $50-52 \%$.

\section{Chemicals}

$\left[{ }^{3} \mathrm{H}\right.$ ]prazosin $\left(24 \mathrm{Ci} \mathrm{mmol}^{-1}\right),\left[{ }^{3} \mathrm{H}\right]$ rauwolscine $(70-85 \mathrm{Ci}$ $\left.\mathrm{mol}^{-1}\right)$ and $\left[{ }^{3} \mathrm{H}\right] \mathrm{DHA}$ (70-85 $\left.\mathrm{Ci} \mathrm{mol}^{-1}\right)$ were purchased from Amersham International plc (Amersham, Bucks., UK). Unlabelled prazosin was a gift from Pfizer France (Paris, France), doxantrazole from The Wellcome Research Laboratories (Beckenham, UK) and MK-886 from Merck Sharp and Dohme (St Louis, MO, USA). Yohimbine, alpenolol and indomethacin were from Sigma (St Quentin Fallavier, France). Trinitrobenzenesulphonic acid was from Fluka (St Quentin Fallavier, France). Other chemicals were of high analytical grade.

\section{Statistical and binding data analysis}

Data were expressed as the mean $\pm S E M$ for each experimental group, with at least three determinations performed in duplicate per group. Data from binding saturation studies were analysed on a personal microcomputer with the nonlinear regression fitting program EBDA/LIGAND. All data were analysed using models for one and two sites of binding. Statistical differences were determined using non-parametric analysis of variance (Kruskal-Wallis test) and Mann-Whitney $U$ test.

\section{RESULTS}

\section{Histological study}

Inflammatory sites were not detected macroscopically or microscopically in intestinal tissue samples from any of the 'sham-treated' groups (Fig. 1a). These were animals in which saline (but not TNBS) was instilled intrajejunally, and that were further given either saline, 

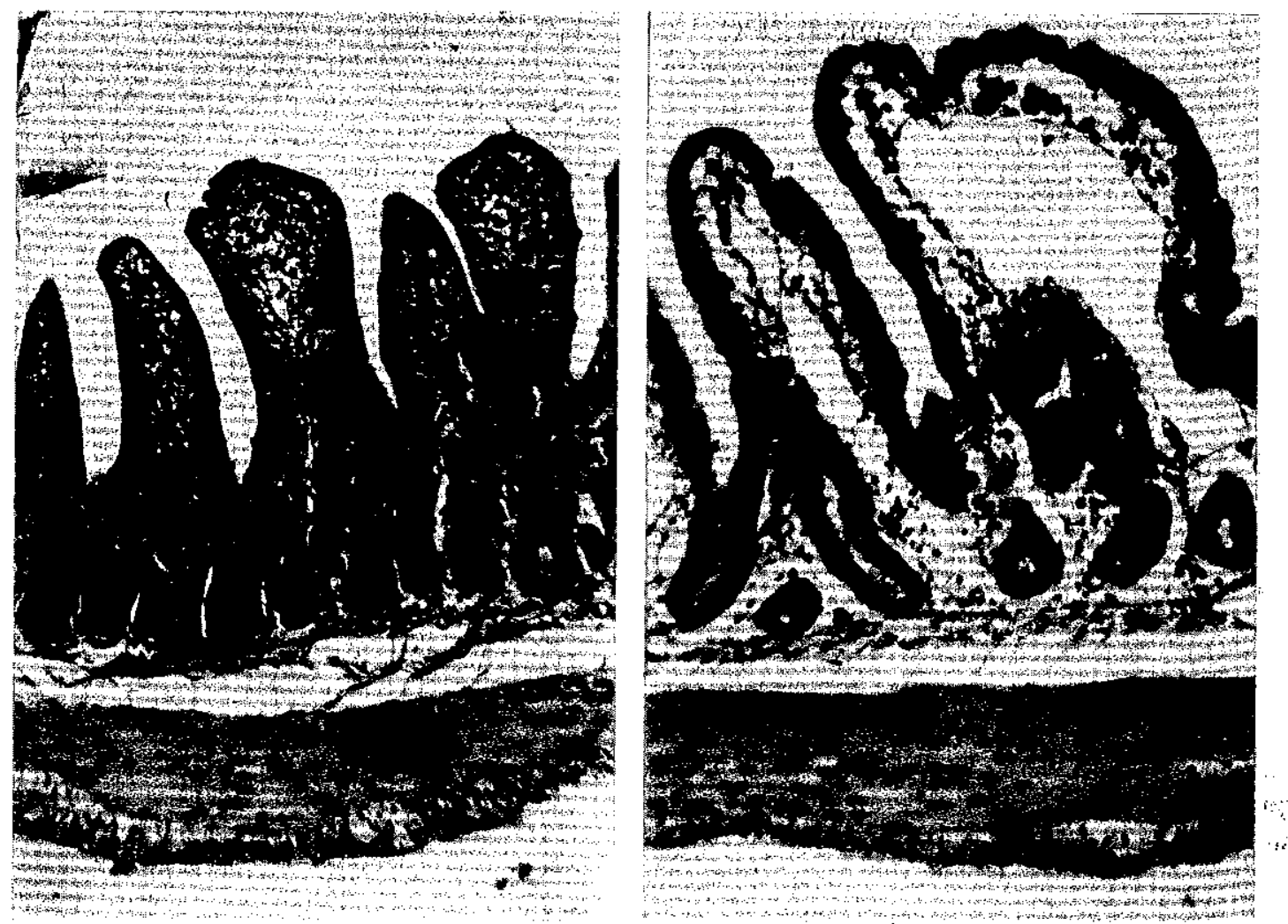

Figure 1 Transverse section of guinea pig ileum from; (a) 'Control group', i.e. animals given $0.9 \% \mathrm{NaCl}$ saline intraperitoneally: normal aspect of the full thickness of the ileal wall; \{b| 'TNBS group', i.e. animals killed 6 days after being given TNBS intrajejunally: note the dramatic enlargement of the lymphatic central capillary of the villi, and that the interglandular spaces of the lamina propria are oedematous. (Original magnification $\times 95$ ).

doxantrazole, indomethacin, MK-886 or L-NAME. In contrast, critical inflammation was observed in intestinal tissue samples taken from animals which received TNBS into the jejunum and saline systemically |'TNBS group $f$. It was characterized by severe transmural inflammation, extended randomly from the injection site in the jejunum, down to the distal ileum. Macroscopically, there were areas of grossly visible bowel wall thickening, associated with major sites of inflammation and/or mucosal ulceration. Microscopically, an enlargement of the central lymphatic capillary in the core of the villi, and an oedema of the lamina propria were observed (Fig. 1b). In some areas, ulcerative foci extended through the mucosa, and the lamina propia was infiltrated by mononucleated cells (mast cells and macrophages), and scattered eosinophils and neutrophils. In the 'TNBSINDO' group (Fig. 2a), the histological profile was similar, thus highlighting the absence of beneficial effects after blockade of prostaglandin synthesis. In contrast, in the 'TNBS-MK' group (Fig. 2b), as well as in the 'TNBSDOX' and 'TNBS-NAME' groups, healing patterns were observed. These latter were characterized macroscopically by the almost normal appearance of the major part of the intestinal length, with focal hyperemia and rare ulcerative foci; microscopically, only oedema and vascular stasis were detected.

\section{Myeloperoxidase activity}

The effect of TNBS on MPO activity, assayed in full thickness ileal wall preparations, is summarized in Table 1. Intrajejunal instillation of TNBS produced a significant, four-fold increase in MPO activity in the ileum $\{P<0.05$, compared to 'Control group' $\}$. In the 'TNBS-treated' groups, this increase in MPO activity was nearly halved $(P<0.05\}$, compared to "TNBS group'), by daily treatment with either doxantrazole, MK-886 or L-NAME, while indomethacin had no effect. In contrast, there were no significant differences in MPO activity values between any of the 'sham-treated' groups (Table 1).

\section{Binding saturation studies}

The characteristics of $\left\{{ }^{3} \mathrm{H}\right\}$ prazosin, $\left.\right|^{3} \mathrm{H} \mid$ rauwolscine and $\left[{ }^{3} \mathrm{H}\right] \mathrm{DHA}$, binding to intestinal smooth muscle mem- 

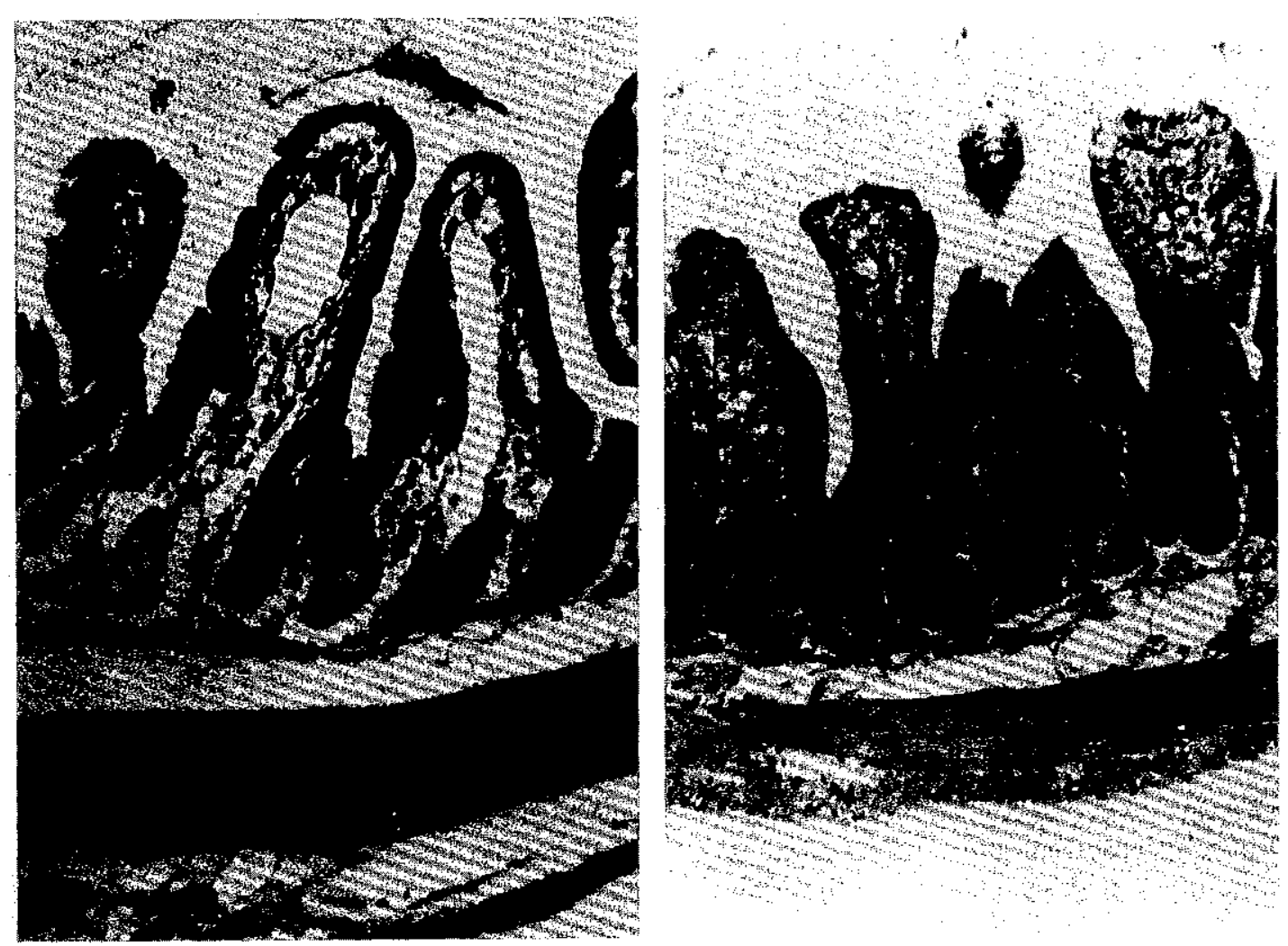

Figure 2 Transverse section of guinea pig ileum from: (a) 'TNBS-INDO group' at day 6 after intraluminal instillation of TNBS: note that the central lymphatic capillary in the core of the villi is distended; (b) 'TNBS-MK group': note the normal appearance of intestinal villosities, lamina propria and muscular layers. (Original magnification $\times 95$ ).

branes from each group under study, are reported in Table 2. For the different experimental groups, specific binding of either radioligand was a saturable process of high affinity. Non-specific binding, determined using unlabelled ligands, increased linearly with radioligand concentrations. For each group and each radioligand, saturation data analysed by the EBDA/LIGAND program were better fitted by monoexponential equations, consistent with interactions at only one class of binding sites. Scatchard analysis, which yielded single straight lines (Fig. 3), and Hill coefficients, which were close to unity for each group (data not shown), confirmed that a single class of non-interacting binding sites was labelled by either radioligand. Adrenoceptor subtype affinities, expressed as dissociation constants $\left(K_{\mathrm{D}}\right)$ for each radioligand, showed no significant differences $(P>0.05\}$ between groups. In contrast, adrenoceptor subtype densities or numbers, expressed as maximal binding capacities $\left(B_{\max }\right)$, varied between groups. Indeed, $B_{\max }$ values for both $\alpha$-adrenoceptor subtypes were significantly $(P<0.05)$ increased at day 6 after TNBS injection in the 'TNBS group', compared to the 'Control group'. Conversely, $B_{\max }$ values for $\beta$-adrenoceptors were decreased $(P<0.05)$ at the same time.
Table 1 MPO activity in 'sham-treated' and 'TNBS-treated' groups in full thickness ileal tissue samples (see text for definition of experimental groups]. MPO activity is expressed for each group as the mean \pm SEM (IU mg ${ }^{-1}$ of protein) of six experiments assayed in duplicate.

Superscripts indicate statistical differences $(P<0.05)$ either from the corresponding 'sham-treated' (a) or from the TNBS group (b)

\begin{tabular}{llllll}
\hline & \multicolumn{1}{c}{ Saline } & \multicolumn{2}{c}{ Doxantrazole } & MK-886 & \multicolumn{2}{l}{ Indomethacin L-NAME } \\
\hline Sham-treated & $0.9 \pm 0.2$ & $1.3 \pm 0.7$ & $0.6 \pm 0.2$ & $0.8 \pm 0.2$ & $0.9 \pm 0.4$ \\
TNBS-treated & $4.2 \pm 0.3^{\mathrm{a}}$ & $2.6 \pm 0.2^{\mathrm{a}, \mathrm{b}}$ & $2.2 \pm 0.4^{\mathrm{a}, \mathrm{b}}$ & $5.0 \pm 0.5^{\mathrm{a}}$ & $1.6 \pm 0.3^{\mathrm{a}, \mathrm{b}}$ \\
\hline
\end{tabular}


Table 2 Binding saturation parameters $\left(B_{\max }\right.$ and $\left.K_{\mathrm{D}}\right)$ for each redioligand in smooth muscle cell membranes from 'sham-treated' and 'TNBS-treated' groups (see text for definition of experimental groups). Binding parameters were calculated by the EBDA/ LIGAND program. Each value was the mean \pm SEM of at least three determinations performed in duplicate per group. The affinities of $\alpha_{1^{-}}, \alpha_{2}$-and $\beta$-adrenoceptor subtypes for their respective radioligands were expressed as equilibrium dissociation constants $\left(K_{\mathrm{D}}\right.$ in $\left.\mathrm{nM}\right)$ and adrenoceptor densities as maximal binding capacities ( $B_{\max }$ in $\mathrm{fmol} \mathrm{mg}^{-1}$ of protein). Superscripts indicate statistical differences from either the corresponding 'sham-treated' $\left.{ }^{\text {a }}\right)$ or the TNBS group $\left({ }^{b}\right)(P<0,05\}$.

\begin{tabular}{|c|c|c|c|c|c|c|c|}
\hline & & & Vehicle & Doxantrazole & MK-886 & Indomethacin & L-NAME \\
\hline$\left[{ }^{3} \mathrm{H}\right]$ prazosin & $\begin{array}{l}\text { Sham-treated } \\
\text { TNBS-treated }\end{array}$ & $\begin{array}{l}B_{\max } \\
K_{\mathrm{D}} \\
B^{\max } \\
K_{\mathrm{D}}\end{array}$ & $\begin{array}{r}28.0 \pm 1.9 \\
0.52 \pm 0.1 \\
50.5^{\mathrm{a}} \pm 7.0 \\
0.74 \pm 0.1\end{array}$ & $\begin{array}{r}29.0 \pm 5.1 \\
0.4 \pm 0.1 \\
33.7^{b} \pm 2.5 \\
0.73 \pm 0.3\end{array}$ & $\begin{array}{r}34.1 \pm 5.0 \\
0.5 \pm 0.3 \\
51.3^{\mathrm{a}} \pm 4.7 \\
0.6 \pm 0.3\end{array}$ & $\begin{array}{r}24.9 \pm 8.1 \\
0.7 \pm 0.3 \\
51.4^{\mathrm{u}} \pm 5.7 \\
0.7 \pm 0.1\end{array}$ & $\begin{array}{r}25.9 \pm 6.3 \\
0.5 \pm 0.3 \\
32.1^{\mathrm{b}} \pm 3.7 \\
0.4 \pm 0.2\end{array}$ \\
\hline$\left.\right|^{3} \mid$ rauwolscine & $\begin{array}{l}\text { Sham-treated } \\
\text { TNBS-treated }\end{array}$ & $\begin{array}{l}B_{\max } \\
K_{\mathrm{D}} \\
B_{\max } \\
K_{D}\end{array}$ & $\begin{aligned} 30.7 & \pm 1.7 \\
2.2 & \pm 0.3 \\
68.5^{\mathrm{a}} & \pm 12.4 \\
2.5 & \pm 1.2\end{aligned}$ & $\begin{array}{r}26,3 \pm 5.6 \\
2.6 \pm 1.0 \\
37,1^{\mathrm{b}} \pm 3.9 \\
2.4 \pm 0.3\end{array}$ & $\begin{array}{r}36.1 \pm 4.8 \\
1.9 \pm 0.4 \\
55.8^{\mathrm{a}} \pm 4.8 \\
2.5 \pm 1.0\end{array}$ & $\begin{array}{r}36.7 \pm 4.2 \\
1.8 \pm 0.7 \\
53.9^{\mathrm{a}} \pm 3.4 \\
2.5 \pm 0.8\end{array}$ & $\begin{array}{r}28.6 \pm 5.5 \\
1.7 \pm 0.9 \\
26.2^{\mathrm{b}} \pm 2.4 \\
2.0 \pm 0.6\end{array}$ \\
\hline$\left[{ }^{3} \mathrm{H}\right] \mathrm{DHA}$ & $\begin{array}{l}\text { Sham-treated } \\
\text { TNBS-treated }\end{array}$ & $\begin{array}{l}B_{\max } \\
K_{\mathrm{D}} \\
B_{\max } \\
K_{\mathrm{D}}\end{array}$ & $\begin{aligned} 326.6 & \pm 14.2 \\
2.2 & \pm 0.6 \\
116.5^{a} & \pm 23.0 \\
2.4 & \pm 0.8\end{aligned}$ & $\begin{array}{c}310.9 \pm 37.5 \\
2.0 \pm 0.6 \\
256.2^{\mathrm{ab}} \pm 27.5 \\
2.9 \pm 1.1\end{array}$ & $\begin{aligned} 335.8 & \pm 20.9 \\
1.7 & \pm 0.5 \\
323.3^{\mathrm{b}} & \pm 12.5 \\
4.0 & \pm 1.1\end{aligned}$ & $\begin{array}{c}358.9 \pm 47.3 \\
3.5 \pm 1.7 \\
145.8^{a} \pm 4.0 \\
3.1 \pm 0.9\end{array}$ & $\begin{aligned} 335.6 & \pm 29.9 \\
4.1 & \pm 1.8 \\
258.0^{\mathrm{b}} & \pm 37.6 \\
3.4 & \pm 1.1\end{aligned}$ \\
\hline
\end{tabular}

We next examined whether the adrenoceptor numbers modifications, observed after TNBS adminis. tration, could be antagonized by treatment with various drugs of putative anti-inflammatory potential. Changes in the $B_{\max }$ values for the $\alpha 1-, \alpha 2$ - and $\beta$-subtypes, respectively, were partly prevented in 'TNBS-treated' groups, by a daily treatment with either doxantrazole, or L-NAME $\{P<0.05$, compared to TNBS alone; Table 2, Fig. 31. In both these latter groups, the increase in $\alpha$ adrenoceptor number was abolished, while the decrease in $\beta$-adrenoceptor number was only prevented by about $60-70 \%$. Daily treatment with MK-886 abolished the $\beta$ adrenoceptor number decrease $(P<0.05$, compared to TNBS alonel, but not the increase in $\alpha 1-$ and $\alpha 2$ adrenoceptor density. Treatment with indomethacin did not reduce the TNBS-induced adrenoceptor changes (Table 2, Fig. 3). On the other hand, $B_{\max }$ values for all adrenoceptor subtypes were not affected by any of the treatments in the 'sham-treated' groups (Table 2). Likewise, $K_{\mathrm{D}}$ values obtained for each radioligand in the ten experimental groups were not significantly different from each other (Table 2).

\section{DISCUSSION}

The present study confirms that the instillation of TNBS into guinea pig small intestine induces an alteration of smooth muscle membrane adrenoceptor number. It consisted of an up-regulation of both $\alpha 1$ - and $\alpha 2$ adrenoceptors, contrasting with a down-regulation of $\beta$ adrenoceptors, as reported in a previous work. ${ }^{4}$ These modifications of adrenoceptor number are associated with histologically observable alterations of small intes tinal mucosa characteristic of inflammation, and an infiltration of polymorphonuclear neutrophils, evidenced by a rise in tissue MPO activity as reported by others in the TNBS-induced model of colitis ${ }^{6}$ or ileitis. ${ }^{12}$

Whether post- or pre-junctionally located, intestinal adrenoceptors, however, are an interesting basis from which to tentatively explain the intestinal motility disturbances associated with gut inflammation. ${ }^{1,2,20}$ Indeed, though smooth-muscle $\beta$-adrenoceptors have been demonstrated to relax the intestine, ${ }^{21}$ the role of the $\alpha 1$ and $\alpha 2$-adrenoceptor subtypes is not well documented. Even the precise, pre- or post-junctional, location of intestinal $\alpha$-adrenoceptors remains an open issue. ${ }^{18,21}$ Nevertheless, previous works have suggested a contractility-stimulating function for both $\alpha$ adrenoceptor subtypes. ${ }^{22,23}$ Therefore, the inverse regulation, occurring at the intestinal level, could be considered as a highly favourable situation to the general motility enhancement observed during intestinal inflammatory processes. ${ }^{1,2}$ Thus, gut inflammation is often associated with structural damage to myenteric plexus neurons, as seen in patients with either inflammatory bowel disease (IBD) ${ }^{24}$ or autonomic neuropathy. ${ }^{25}$ Loss of noradrenergic nerve supply to the gut has been reported in connection with inflammation, such as that of the intestine of rats infected by Trichinella spiralis. ${ }^{3}$ This functional denervation is likely to explain, at least in part, the observed increase in $\alpha$-adrenoceptor numbers in the inflammed tissue, as a result of a drop of the circulating agonist noradrenaline. Nevertheless, it hardly explains the parallel decrease in $\beta$-adrenoceptors, 

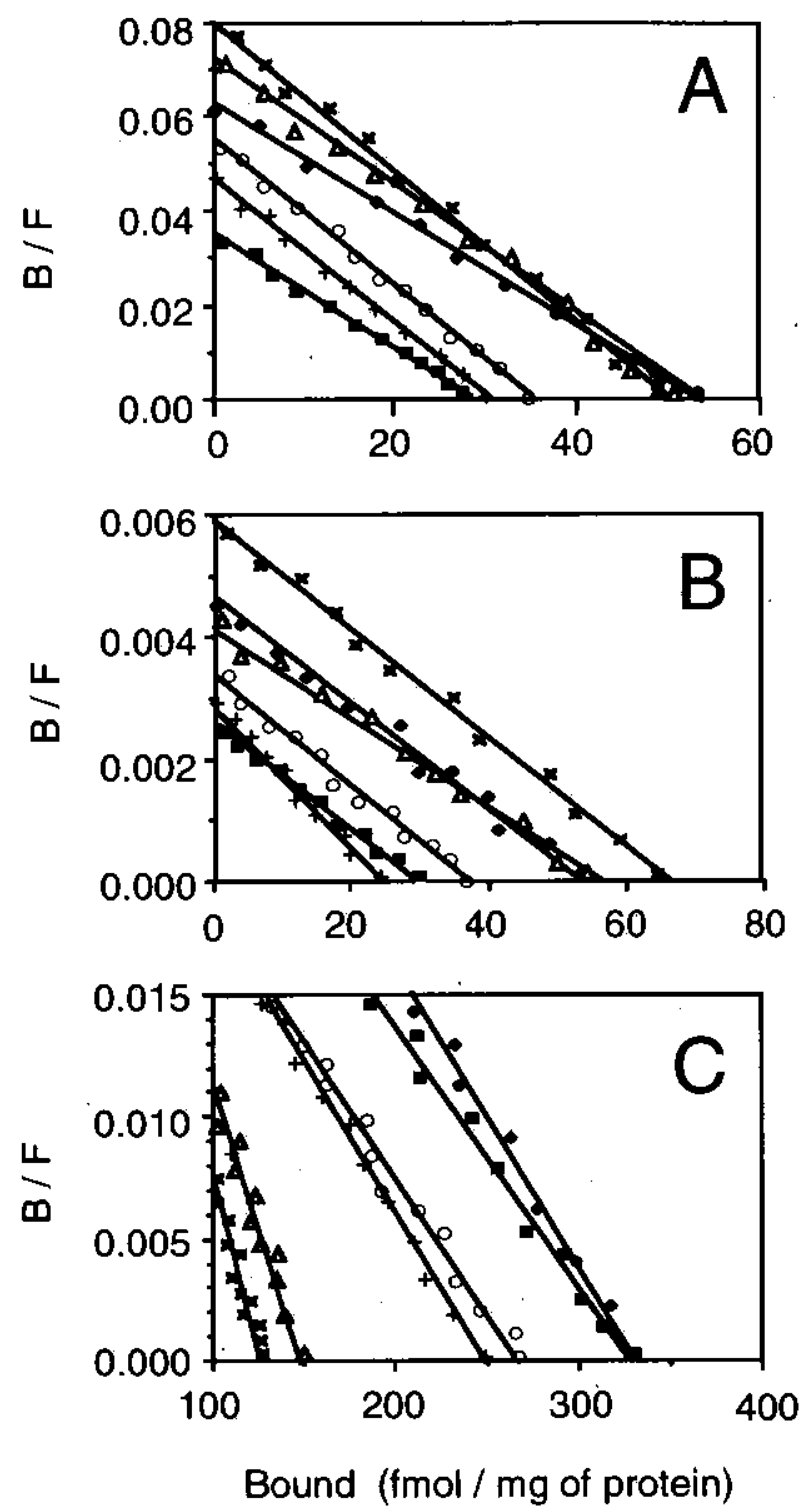

Figure 3 Scatchard plots of adrenoceptor saturation binding data for the 'Control group' and all 'TNBS-treated' groups. The ratio of bound to free $\{\mathrm{B} / \mathrm{F}\}$ is expressed as a function of bound $\left[{ }^{3} \mathrm{H}\right]$ prazosin $(\alpha \mathrm{l}$-adrenoceptors; $\mathrm{A}),\left[{ }^{3} \mathrm{H}\right.$ |rauwolscine $(\alpha 2$-adrenoceptors; $B)$ and $\left.\mid{ }^{3} \mathrm{H}\right] \mathrm{DHA}(\beta$-adrenoceptors; $\mathrm{C})$. Each plot is representative of at least three determinations performed in duplicate (see Methods section for definition of experimental groups!. $\square$ Control, $\times$ TNBS, $\triangle$ TNBS-INDO,

- TNBS-MK, + TNBS-NAME, $\bigcirc$ TNBS-DOX.

which is probably controlled by a different mechanism. On the other hand, gut inflammation has been associated with hyperplasia and hypertrophia of the intestinal muscle layers. ${ }^{26}$ Nevertheless thickening of intestinal wall is also unlikely to account for the observed changes, as receptor number is normalized to protein contents in the present study.
According to the present data, it seems that intestinal adrenoceptor density modifications could also result from the enhanced release of inflammatory mediators. These mediators could well be directly responsible for the intestinal motility disturbances, but, by modifying the number of $\alpha$-and $\beta$-adrenoceptors, they exert an additional influence on smooth muscle contractility.

An increased synthesis of cycloxygenase metabolites has been reported during the inflammatory response of the gut. ${ }^{9}$ However, our attempt to inhibit the cycloxygenase pathway with indomethacin failed to revert, or attenuate, changes in adrenoceptor numbers, thus suggesting that prostanoids do not play a major role in this process. In our study, indomethacin treatment neither improves not exacerbates TNBS-induced intestinal injury, as evidenced by the histological picture obtained (Fig, 2a), and the level of intestinal tissue MPO activity, which remains high. The present results are consistent with investigations with the TNBS model, showing that indomethacin, though effective in inhibiting prostanoid synthesis without effect on 5lipoxygenase products, did not reduce the severity of intestinal inflammation. ${ }^{27}$ However, treatments with prostaglandin analogues have shown a reduction of the extent of gut damage, induced by experimental inflammation. ${ }^{28}$ Therefore, further experiments will be required to precise the role of cycloxygenase products, in the overall intestinal response to TNBS inflammation.

The lipooxygenase synthesis inhibitor MK- $886^{14}$ prevented the decrease in $\beta$-adrenoceptor density but was apparently unable to prevent the increase in $\alpha$ adrenoceptor number. Although the mechanisms whereby $\alpha$ - and $\beta$-adrenoceptor subtypes were differently affected by MK-886 treatment remain to be elucidated, this observation illustrates the fact that changes in $\alpha$-and $\beta$-adrenoceptor subtypes certainly involve different mechanisms, with leukotrienes being implicated in the regulation solely of the $\beta$-adrenoceptor number. Our data also show that MK-886 significantly reduces MPO activity in TNBS-treated animals, in agreement with results supporting a role for LTs, particularly $\mathrm{LTB}_{4}$ and $\mathrm{LTD}_{4}$, in the pathogenesis of intestinal inflammation. ${ }^{9,10,29}$ They are also consistent with a chemotactic role for LTs on polymorphonuclear neutrophils, as similar doses of MK-886 accelerate healing in TNBS-induced colitis ${ }_{t}{ }^{29}$ and are effective in inhibiting $\mathrm{LTB}_{4}$ synthesis for more than $24 \mathrm{~h}{ }^{30}$

Daily treatment with the NO-synthase inhibitor $\mathrm{L}^{-}$ NAME prevented the changes in smooth muscle adrenoceptor number, as well as the mucosal injury and the rise in intestinal MPO activity observed after TNBS treatment. These findings support the involvement of NO in TNBS-induced intestinal inflammation, which 
agrees with the increased concentrations of nitrites reported either in patients with ulcerative colitis, ${ }^{31}$ or in experimental models of chronic inflammation. ${ }^{11}$ Interestingly, Miller et a1. ${ }^{12}$ recently reported an increased MPO activity in intestinal tissues of healthy guinea pigs treated with L-NAME, and an improvement of TNBS-induced ileitis by treatment with this NO synthase inhibitor. In comparison, in our study we used a three-fold lower dose of L-NAME which was without effect in 'sham-treated' animals, while it efficiently reduced TNBS-induced tissue injury and enhancement of MPO activity when administered to TNBS-treated animals. However, we have no data on the mechanisms whereby NO could act to directly or indirectly modulate intestinal smooth muscle adrenoceptors during the inflammatory process. TNBS is thought to release radicals, as it decomposes in the mucosa, and these may interact with $\mathrm{NO}^{32}$ It is possible that the beneficial effects of L-NAME on inflammatory damages, and the preyention of adrenoceptor changes, could result from avoiding interactions between NO, which is not generated owing to the action of L-NAME, and TNBS-released free radicals.

Finally, daily treatment with doxantrazole, a mast cell stabilizer acting on the mast cell populations of both intestinal mucosa and connective tissue ${ }_{r}{ }^{13}$ prevented TNBS-induced changes in smooth muscle adrenoceptors, and reduced the increase in MPO activity, therefore suggesting the involvement of mast cells in the intestinal response to TNBS. In other inflammatory models, the release of mast cell mediators has been associated with mucosal injury. ${ }^{33}$ In addition, others have shown that mast cell hyperplasia and activation occur during intestinal inflammation, ${ }^{7,8}$ and that mast cell stabilizers reduce the severity of inflammatory damage. ${ }^{34,35}$ Moreover, studies demonstrating the close apposition of nerves and mast cells in the intestinal mucosa, ${ }^{36}$ as well as an alteration of the autonomic nervous supply associated with mast cell degranulation, ${ }^{37}$ suggest that products of mast cell degranulation, such as LTS, NO or cytokines, could be the regulatory mediators tentatively involved in both TNBS-induced intestinal adrenoceptor changes, and tissue damage. ${ }^{33,38}$

In conclusion, the present work brings new evidence that mast cell degranulation, nitric oxide generation and leukotriene production could be major mechanisms involved in the intestinal smooth muscle adrenoceptor regylation observed in the guinea pig during TNBSinduced gut inflammation. In contrast, evidence for the involvement of prostanoids has not been obtained. Secondarily, our results point out a special relationship between LTs and $\beta$-adrenoceptor down-regulation, whereas mast cells and NO are involved in the. regu- lation of both $\alpha$-and $\beta$-subtypes, Finally, our work brings additional evidence for the existence of an extended network relating inflammatory cells, intestinal smooth muscle cells and the autonomic nervous system, especially its adrenergic component.

\section{ACKNOWLEDGEMENT}

The authors thank the Institut National de la Recherche Agronomique for its financial support.

\section{REFERENCES}

1 Vermillion DL, Huizinga JD, Riddell $\mathrm{RH}$, Collins SM. Altered small intestinal smooth muscle function in Crohn's disease. Gastroenterology 1993; 104:1692-9.

2 Castro GA, Badial-Aceves F, Smith IW, Dudrick SI, Weisbrodt NW. Altered small bowel propulsion associated with parasitism. Gastroenterology 1976, 71:620-5.

3 Swain MG $_{r}$ Blennerhassett PA, Collins SM. Impaired sympathetic nerve function in the inflamed rate intestine. Gastroenterology 1991; 100:675-82.

4 Martinolle JP, Moré J, Dubech N, Garcia-Villar R. Inverse regulation of $\alpha$ - and $\beta$-adrenoceptors during trinitroben * zenesulfonic acid (TNB)-induced inflammation in guineapig small intestine. Life Sciences 1993, 52:1499-1508.

5 Dvorak AM. Ultrastructure of human gastrointestinal system. Interaction among mast cells, cosinophils, nerves and muscle in human disease. In: Snape WJ, Collins SM, eds. Effect of immune cells and inflammation on smooth muscle and enteric nerves. Boca Raton, Fla: CRC Press Inc, 199):150-8.

6 Morris GP, Beck PL, Herridge MS, Depew WT, Szewczuk MR, Wallace JL, Hapten-induced model of chronic inflammation and ulceration in the rat colon. Gastroenterology 1989, 96:795-803.

7 Balázs M, Illyés G, Vadász G. Mast cells in ulcerative colitis. Quantitative and ultrastructural studies. Virchows Arch Cell Pathol 1989; 57:353-60.

8 Befus AD, Johnston N, Bienenstock J. Nippostrongylus brasiliensis: mast cells and histamine levels in tissues of infected and normal rats. Exp Parasitol 1979; 48:1-8,

9 Lauritsen K, Laursen LS, Bukhave K, Rask-Madsen J. In vivo profiles of eicosanoids in ulcerative colitis, Crohn's colitis and Clostridium difficile colitis. Gastroenterology 1988; 95:11-17.

10 Zipser RD, Nast CC, Lee M, Kao HW, Duke R. In vivo production of leukotriene $\mathrm{B} 4$ and leukotriene $\mathrm{C} 4$ in rabbit colitis. Relationship to inflammation. Gastroenterology 1987; 92:33-9.

11 Miller MIS, Zhang XJ. Sadowska-Krowicka H, Chotinaruemol S, McIntyre JA, Clark DA, Bustamante SA. Nitric oxide release in response to gut injury. Scand / Gastroenterol $1993 ; 28: 149-54$.

12 Miller MIS, Sadowska-Krowicka $\mathrm{H}$, Chotinaruemol S, Kakkis JL, Clark DA. Amelioration of chronic ileitis by nitric oxide synthase inhibition. I Pharmacol Exp Ther 1993; 264:11-16.

13 Marzio L, Blennerhassett P, Vermillion D, Chiverton $S$, 
Collins S. Distribution of mast cells in intestinal muscle of nematode-sensitized rats. Am / Physiol 1992; 262;G47782.

14 Gillard J, Ford-Hutchinson AW, Chan C, et al. L-663,536 (MK-886) [3-(1-4-chlorobenzyl)-3-t-butyl-thio-5-isopropylindol-2-yl|-2,2-dimethylpropanoic acid), a novel orally active leukotriene biosynthesis inhibitor. Can / Physiol Pharmacol 1989; 67:456-64.

15 Wallace IL, Keenan CM, Gale D, Shoupe TS. Exacerbation of experimental colitis by nonsteroidal anti-inflammatory drugs is not related to elevated leukotrienc $B_{4}$ synthesis. Gastroenterology 1992, 102:18-27.

16 Bradley PP, Priebat DA, Christensen RD, Rothstein G. Measurement of cutaneous inflammation: estimation of neutrophil content with an enzyme marker. / Invest Dermatol 1982; 78:206-9.

17 Matlib MA, Crankshaw J, Garfield RE, Crankshaw DI, Kwan CY, Branda LA, Daniel EE. Characterization of membrane fractions and isolation of purified plasma membranes from rat myometrium. / Biol Chem 1979; 254:1834 40 .

18 Wikberg IES, Lefkowitz RJ. Alpha2 adrenergic receptors are located prejunctionally in the Auerbach's plexus of the guinea pig small intestine: direct demonstration by radioligand binding. Life Sciences 1982; 31:2899-905.

19 Kostka P, Sipos SN, Kwan C, Niles LP, Daniel EE. Identification and characterization of presynaptic and postsynaptic beta adrenoceptors in the longitudinal smooth muscle/ myenteric plexus of dog ileum. / Pharmacol Exp Ther 1989, 251:305-10.

20 Morteau O, Moré J, Pons L, Buéno L. Platelet-activating factor and interleukin 1 are involved in colonic dysmotility in experimental colitis in rats. Gastroenterology 1993; 104:47-56.

21 Fox DA, Bass P. Ablation of the myenteric plexus impairs alpha but not beta adrenergic receptor-mediated mechanical responses of rat jejunal longitudinal muscle. / Pharmacol Exp Ther 1986; 239:9-14.

22 Sultan A, Allesher HD, Jang E, Rausa I, Daniel EE, $\alpha 2$ adrenergic receptors on the circular smooth muscle of canine small intestine. Can / Physiol Pharmacol 1991; 69:837-40,

23 Bauer $V$, Kuriyama $H$. Homogeneous and nonhomogeneous distribution of inhibitory and excitatory adrenoceptors in the longitudinal muscle of the guinea-pig ileum. Br / Pharmacol 1982; 76:603-11.

24 Dvorak AM, Osaje JE, Monahan RA, Dickersin GR. Crohn's disease: Transmission electron microscopic studies. III. Target tissues. Proliferation of and injury to smooth muscle and the autonomic nervous system. Human Pathol 1980; 11:620-34.

25 Lindgren S, Lilja B, Rosén I, Sundkvist G. Disturbed autono- mic nerve function in patients with Crohn's disease. Scand / Gastroenterol 1991, 26:361-6.

26 Blennerhassett $\mathrm{MG}$, Vignjevic $\mathrm{P}$, Vermillion $\mathrm{DL}$, Collins SM. Inflammation causes hyperplasia and hypertrophy in smooth muscle of rat small intestine. Am I Physiol 1992; 262:G1041-6.

27 Boughton-Smith NK, Wallace JL, Morris GP, Whittle BJR. The effect of anti-inflammatory drugs on eicosanoid formation in a chronic model of inflammatory bowel disease in the rat. Br / Pharmacol 1988; 94:65-72.

28 Torsher KI, Empey LR, Fedorak RN. Misoprostol therapy following trinitrobenzene sulfonic acid-induced colitis accelerates healing. Prostagland Leuk Essent Fatty Acids 1992, 45:275-81.

29 Pons L, Droix-Lefaix MT, Buéno L. Leukotriene D4 participates in colonic transit disturbances induced by intracolonic administration of trinitrobenzene sulfonic acid in rats. Gastroenterology 1992; 102:149-56.

30 Wallace JL, Keenan CM. An orally active inhibitor of leukotriene synthesis accelerates healing in a rat model of colitis. Am I Physiol 1990; 258:G527-34.

31 Roediger WEW, Lawson MJ, Nance SH, Radcliffe BC. Detectable colonic nitrite levels in inflammatory bowel disease - Mucosal or bacterial malfunction? Digestion 1986, 35:199-204.

32 Grisham MB, Volkmer C, Tso P, Yamada T. Metabolism of trinitrobenzene sulfonic acid by the rat colon produces reactive oxygen species. Gastroenterology 1991, 101:5407.

33 Perdue MH, Ramage JK, Burget D, Marshall J, Masson S. Intestinal Mucosal injury is associated with mast cell activation and leukotriene generation during Nippostrongylusinduced inflammation in the rat. Digest Dis Sci 1989; 34:724-31.

34 Karmeli F, Eliakim R, Okon E, Rachmilewitz D. Gastric mucosal damage by ethanol is mediated by substance $P$ and prevented by ketotifen, a mast cell stabilizer. Gastroenterology 1991; 100:1206-16.

35 Grace RH, Gent AE, Hellier MD. Comparative trial of sodium cromoglycate enemas with prednisolone enemas in the treatment of ulcerative colitis. Gut 1987; 28:88-92.

36 Stead RH, Dixon MF, Bramwell NH, Riddel RH, Bienenstock I. Mast cells are closely apposed to nerves in the human gastrointestinal mucosa. Gastroenterology 1989; 97:575-85.

37 Yoney Y. Autonomic nervous alterations and mast cell degranulation in the exacerbation of ulcerative colitis. Ipn I Gastroenterol 1987; 84:1045-56.

38 Hurst S, Collins SM. Interleukin- $1 \beta$ modulation of norepinephrine release from rat myenteric nerves. Am / Physiol $1993 ; 264: G 30-5$. 
